\title{
Digenea of Hoplias intermedius and Hoplias malabaricus (Actinopterygii, Erythrinidae) from upper São Francisco River, Brazil
}

\author{
Digenea de Hoplias intermedius e Hoplias malabaricus (Actinopterygii, Erythrinidae) \\ do alto rio São Francisco, Brasil \\ Danielle Priscilla Correia Costa ${ }^{1}$; Cassandra Moraes Monteiro²; Marilia Carvalho Brasil-Sato ${ }^{2 *}$
}

\begin{abstract}
'Programa de Pós-graduação em Ciências Veterinárias, Departamento de Parasitologia Animal, Universidade Federal Rural do Rio de Janeiro - UFRRJ, Seropédica, RJ, Brasil

${ }^{2}$ Departamento de Biologia Animal, Universidade Federal Rural do Rio de Janeiro - UFRRJ, Seropédica, RJ, Brasil
\end{abstract}

Received November 7, 2014

Accepted March 11, 2015

\begin{abstract}
A total of 103 specimens of Hoplias intermedius (Günther, 1864) and 86 specimens of H. malabaricus (Bloch, 1794) from the upper São Francisco River, State of Minas Gerais were collected between April 2011 and August 2013, and their parasitic fauna were investigated. Four species of Digenea were found: metacercariae of Austrodiplostomum sp., and Ithyoclinostomum sp.; and adult specimens of Phyllodistomum spatula Odhner, 1902, and Pseudosellacotyla lutzi (Freitas, 1941) Yamaguti, 1953. The prevalence of the metacercariae was higher than that of the adult digeneans of erythrinids from the upper São Francisco River as a result of piscivorous feeding habits of these adult erythrinids. The presence of metacercariae and adult digeneans indicate that they act as intermediate and definitive hosts, respectively, in their biological cycles. Hoplias intermedius is a new host for the four species of Digenea, and the São Francisco River basin is a new location for the known geographical distributions of $P$. spatula and $P$. lutzi.
\end{abstract}

Keywords: Digenea, Hoplias, parasite ecology, parasites of freshwater fish, São Francisco River.

\section{Resumo}

Um total de 103 espécimes de Hoplias intermedius (Günther, 1864) e 86 de H. malabaricus (Bloch, 1794), provenientes do alto Rio São Francisco, Estado de Minas Gerais, foram coletados entre abril de 2011 e agosto de 2013 e tiveram sua fauna parasitária investigada. Quatro espécies de digenéticos foram encontradas: metacercárias de Austrodiplostomum sp. e de Ithyoclinostomum sp.; e espécimes adultos de Phyllodistomum spatula Odhner, 1902 e de Pseudosellacotyla lutzi (Freitas, 1941) Yamaguti, 1953. A prevalência das metacercárias foi mais elevada do que as registradas para os digenéticos adultos dos eritrinídeos do alto Rio São Francisco, resultante da dieta preferencialmente piscívora desses peixes adultos. A presença de metacercárias e de espécimes adultos de digenéticos indicam que os peixes atuam como hospedeiros intermediários e definitivos, respectivamente, nos seus ciclos biológicos. Hoplias intermedius constitui novo hospedeiro para as quatro espécies de Digenea encontradas e a bacia do Rio São Francisco constitui uma nova localidade para a distribuiçáo geográfica conhecida de $P$. spatula e de $P$. lutzi.

Palavras-chave: Digenea, Hoplias, ecologia de parasitos, parasitos de peixes de água doce, Rio São Francisco.

\section{Introduction}

The Hoplias group, allocated in Erythrinidae, is constituted by eleven species of carnivorous fish, for which the main food items are other fish (LOUREIRO \& HAHN, 1996; CARVALHO et al., 2002; ALVIM \& PERET, 2004). These species are distributed throughout

${ }^{*}$ Corresponding author: Marilia Carvalho Brasil-Sato. Departamento de Biologia Animal, Universidade Federal Rural do Rio de Janeiro - UFRRJ, BR465, Km 7, CP 74539, CEP 23851-970, Seropédica, RJ, Brasil. e-mail: mcbsato@gmail.com.
South America and are abundant in the basins of the Amazon, the South Atlantic (except in the southeastern stretch), São Francisco, and Paraná; their dispersal capacity and wide distribution are attributed to their ability to survive in environments with little oxygen and/or their endurance during long periods of fasting (OYAKAWA et al., 2006). Hoplias intermedius (Günther, 1864) (Hoplias lacerdae species group, following OYAKAWA \& MATTOX, 2009) and Hoplias malabaricus (Bloch, 1794) are 
popularly known in Brazil as "trairão" (in Portuguese) and "traira” (in Portuguese), or trahira, respectively, and they are abundant in the São Francisco basin (BRITSKI et al., 1988).

There are no records of parasites in $H$. intermedius, but there are several groups of parasites that have been recorded that parasitize Hoplias spp. in different Brazilian basins (see TRAVASSOS et al., 1964; THATCHER, 1991; KOHN et al., 2007; ROCHA, 2011; COHEN et al., 2013).

After some research on the presence of Digenea in erythrinids was published, Kohn et al. (2007) compiled the existing information on digenean parasites of South American fish and recorded the presence of adult specimens of Pseudallacanthochasmus grandispinis Velasquez, 1961, Thometrema overstreeti (Brooks, Mayes and Thorson, 1979), Pseudosellacotyla lutzi (Freitas, 1941) Yamaguti 1953, and Prosthenhystera sp. in H. malabaricus. Kohn et al. (2007) included P. grandispinis among the parasites of erythrinid fish, despite that Jones et al. (2005) already had considered the record of P. grandispinis to be invalid, since this species is a parasite of marine perciform fish and not of freshwater characiform fish. Rocha (2011) listed the parasites of $H$. malabaricus from different Brazilian basins and recorded the following digeneans: metacercariae of Clinostomum complanatum Rudolphi, 1814, Ithyoclinostomum dimorphum (Diesing, 1850), Austrodiplostomum compactum (Lutz, 1928), and of Sphincterodiplostomum musculosum Dubois, 1936; and adult specimens of $P$. lutzi. Following these compilations, no other species of digenean were found to parasitize $H$. malabaricus.

The aims of this paper were to present, for the first time, the species of digenean parasites of $H$. intermedius and $H$. malabaricus from the São Francisco Basin.

\section{Materials and Methods}

The specimens of two species of Hoplias were collected in the upper São Francisco basin ( $18^{\circ} 12^{\prime} 32^{\prime}$ S; $45^{\circ} 15^{\prime} 41^{\prime}$ W), downstream from the Três Marias Reservoir, near the municipality of Três Marias, State of Minas Gerais, Brazil. A total of 103 specimens of $H$. intermedius [standard length: $31(14-48 \mathrm{~cm})]$, and 86 specimens of $H$. malabaricus [standard length: $25(17-35 \mathrm{~cm})$ ] were collected by staff members at the Centro Integrado de Recursos Pesqueiros e Aquicultura (CIRPA) of the Companhia de Desenvolvimento dos Vales do São Francisco e do Parnaíba (CODEVASF) between April 2011 and August 2013. The fish were transported to the Laboratório de Ictiologia of the CIRPA, where they were identified according Britski et al. (1988). Valid names of the fish were used according to Oyakawa (2003) and Oyakawa \& Mattox (2009). The parasites were processed and preserved according to Amato et al. (1991). Voucher specimens of $H$. intermedius and H. malabaricus were deposited in the Coleção de Peixes of the Museu de Zoologia of the Universidade de São Paulo (MZUSP), State of São Paulo, Brazil under the numbers 95163 and 95162, respectively. All mounted specimens were examined under an Olympus BX41 microscope with phase contrast; the measurements are presented in millimeters ( $\mathrm{mm}$ ), and the mean are followed by the minimum and maximum values, which are presented in parentheses. Dates on morphology and measurements are compared with those of the published scientific literature. Parasites were classified according to Kanev et al. (2002), Niewiadomska (2002) (metacercariae), Campbell (2008), and Bray (2008) (adult digeneans). The identification of the metacercariae is according to Kohn et al. (1995), Niewiadomska (2002), and Benigno et al. (2014), and the identification of adult specimens was done according to Fernandes (1984) and Kohn et al. (1985). The ecological descriptors, prevalence, mean intensity, and mean abundance followed the methods of Bush et al. (1997). Voucher specimens of the parasites were deposited in the Coleção Helmintológica of the Instituto Oswaldo Cruz (CHIOC), Rio de Janeiro, Brazil, under the numbers indicated in the Results section.

\section{Results}

A total of 103 specimens of $H$. intermedius was examined. Twenty-three $(22.33 \%)$ were parasitized by at least one species of digenean; seven (6.79\%) were parasitized by Austrodiplostomum sp., eleven $(10.67 \%)$ by Ithyoclinostomum sp., three $(2.91 \%)$ by Phyllodistomum spatula Odhner, 1902, and two (1.94\%) by Pseudosellacotyla lutzi (Freitas, 1941) Yamaguti, 1953. Two (1.94\%) $H$. intermedius were simultaneously infected by Austrodiplostomum sp. and Ithyoclinostomum sp.. A total of 86 specimens of $H$. malabaricus was examined, and $16(18.64 \%)$ were parasitized by one species of digenean: seven (8.13\%) by Austrodiplostomum sp., five (5.81\%) by Ithyoclinostomum sp., and four (4.65\%) by P. spatula. The values for the prevalence, mean intensity, and mean abundance of digeneans recorded in $H$. intermedius and $H$. malabaricus are presented in Table 1 .

Diplostomidae Poirier, 1886

Austrodiplostomum Szidat \& Nani, 1951

\section{Austrodiplostomum sp.}

Measurements: (Based on five specimens "in toto" - metacercariae) Body: $1.04(1.02-1.08) \times 0.50(0.49-0.53)$; oral sucker: $0.04(0.04)$ $\times 0.04$ (0.04); ventral sucker: $0.01(0.01) \times 0.01(0.01)$; pharynx: $0.05(0.04 \times 0.06)$; and tribocitic organ: $0.22(0.22 \times 0.23)$.

Hosts: Hoplias intermedius (Günther, 1864) (new host) and Hoplias malabaricus (Bloch, 1794).

Site of infection: Eyes.

Voucher specimens: CHIOC 37982 (H. intermedius); CHIOC 37983 ( $H$. malabaricus).

Remarks: These metacercariae that have a site inside the eyes of fish (retina, vitreous humor, aqueous humor, and/or crystalline) can cause injuries; in extreme cases, its presence can cause exophthalmos, retinal detachment, lens opacity, and blindness (MARTINS et al., 1999; SZIDAT \& NANI, 1951).

The metacercariae of this study are similar to those reported by Kohn et al. (1995) and Yamada et al. (2008), who identified the metacercariae as Austrodiplostomum compactum (Lutz, 1928). The metacercariae occurs in fish and amphibians, and the adult specimens parasitize birds or mammals (NIEWIADOMSKA, 2002).

In the São Francisco River, Brasil-Sato (2003) reported the presence of metacercariae of the Austrodiplostomum sp. (as Diplostomum sp.) in the eyes of Prochilodus argenteus Agassiz, 1829, Trachelyopterus galeatus (Linnaeus, 1766), Conorhynchos conirostris Val., 1840, and Pimelodus maculatus Lacépède, 1803; later, Santos-Clapp \& Brasil-Sato (2014), as well as Sabas \& 
Table 1. Ecological describers (prevalence, mean intensity and mean abundance) of digenean species of Hoplias spp. (Erythrinidae) from the upper São Francisco River, State of Minas Gerais, Brazil.

\begin{tabular}{|c|c|c|c|c|c|c|}
\hline \multirow[b]{2}{*}{ Digenean species } & \multicolumn{3}{|c|}{ Hoplias intermedius (Günther, 1864) $(\mathrm{n}=103)$} & \multicolumn{3}{|c|}{ Hoplias malabaricus (Bloch, 1794) $(\mathrm{n}=86)$} \\
\hline & Prevalence (\%) & $\begin{array}{l}\text { Mean intensity } \\
\text { (range) }\end{array}$ & Mean abundance & Prevalence (\%) & $\begin{array}{l}\text { Mean intensity } \\
\text { (range) }\end{array}$ & Mean abundance \\
\hline Metacercariae & & & & & & \\
\hline Austrodiplostomum sp. & 6.79 & $3.42(1-12)$ & 0.23 & 8.13 & $4.57(1-12)$ & 0.37 \\
\hline $\begin{array}{l}\text { Ithyoclinostomum sp. } \\
\text { Adult Specimens }\end{array}$ & 10.67 & $2.54(1-7)$ & 0.27 & 5.81 & $2.00(1-6)$ & 0.11 \\
\hline $\begin{array}{l}\text { Phyllodistomum spatula } \\
\text { Odhner, } 1902\end{array}$ & 1.94 & $2.00(2)$ & 0.03 & 4.65 & $1.50(1-3)$ & 0.06 \\
\hline $\begin{array}{c}\text { Pseudosellacotyla lutzi } \\
\text { (Freitas, 1941) } \\
\text { Yamaguti 1953 }\end{array}$ & 1.94 & $276(201-301)$ & 5.36 & - & - & - \\
\hline
\end{tabular}

Brasil-Sato (2014), recorded these metacercariae (as A. compactum) in the eyes of the Cichla kelberi Kullander \& Ferreira, 2006 and Pimelodus pohli Ribeiro \& Lucena, 2006, respectively.

The prevalence (P) of Austrodiplostomum sp. varied among Siluriform fish (omnivorous adult representatives of Pimelodidae) from São Francisco River, and their rates were occasionally lower than that of adult digenean species in the parasite communities (P. maculatus: $\mathrm{P}=20.5 \%$, lower than that of Plehniella coelomica Szidat, 1951 (= Sanguinicola coelomica (Szidat, 1951) - P=21.3\%) among other adult digeneans (BRASIL-SATO \& PAVANELLI, 2004); Conorhynchos conirostris (Val., 1840): $\mathrm{P}=8.3 \%$, similar to metacercariae of the Clinostomum sp., and lower than that of Creptotrema creptotrema Travassos, Artigas \& Pereira, 1928, and Paleocryptogonimus claviformis Szidat, 1954 - both $\mathrm{P}=16.7 \%$ (BRASIL-SATO \& SANTOS, 2005); and P. pohli: $\mathrm{P}=35.5 \%$, higher than the Digenea community (SABAS \& BRASIL-SATO, 2014).

Metacercariae of Austrodiplostomum sp. have been registered in Hoplias spp. from several Brazilian basins, as well as in different hosts (see RAMOS et al., 2013). In some studies, those metacercariae showed a higher prevalence rate than the trahiras from the upper São Francisco River ( $\mathrm{P}=60.7 \%$ in the Paraná River (SANTOS et al., 2012), and $\mathrm{P}=57.1 \%$ in the mid-Doce River, State of Minas Gerais (BELEI et al., 2013). For the perciforms, the prevalence of metacercariae has been high in some studies, and it was higher than that for cichlids ( $\mathrm{P}=59.8 \%$ in $C$. kelberi) from the São Francisco River (SANTOS-CLAPP \& BRASIL-SATO, 2014), ( $\mathrm{P}=65.0 \%$ in $C$. kelberi (=Cichla monoculus) from the Paraná River (MACHADO et al., 2005), $\mathrm{P}=92.7 \%$ and $\mathrm{P}=58.6 \%$ in Geophagus proximus (Castelnau, 1855) from the Tietê River and from the Ilha Solteira Reservoir, both in the State of São Paulo (ZICA et al., 2010; ZAGO et al., 2013), respectively, and $\mathrm{P}=71.9 \%$ and $\mathrm{P}=60.0 \%$ in Satonoperca pappaterra (Haeckel, 1840) from the Paraná and Tietê Rivers (MACHADO et al., 2005; PAES et al., 2010a), respectively). Among the Sciaenidae representatives, the high prevalence rates were even more pronounced in Plagioscion squamosissimus (Heckel, 1840), and they fluctuated between 90\% and 100\% in the Paraná (MACHADO et al., 2005; KOHN et al., 2011; SANTOS et al., 2012) and Tietê Rivers (PAES et al., 2010b); they were also high in registers from many other Brazilian states. This introduced fish species have been described as possible entry points for the metacercariae in the Brazilian limnic systems (BELEI et al., 2013).

In Brazil, with respect to the presence of $A$. compactum (considering the records of metacercariae of the Austrodiplostomum sp. or Diplostomum sp.) in the eyes of fish, their parasitic indices in different water systems were compiled by Ramos et al. (2013).

The present record of metacercariae of the Austrodiplostomum sp. in $H$. intermedius expands the diverse list of hosts parasitized by these metacercariae.

Clinostomidae Lühe, 1901

Ithyoclinostomum Witenberg, 1925

\section{Ithyoclinostomum sp.}

Measurements: (Based on four specimens "in toto" - metacercariae) Body: $22(15.0-33.0) \times 2.39(1.50-4.00)$; oral sucker: $0.31(0.30-0.32)$ $\times 0.53(0.52-0.57)$; ventral sucker: $0.98(0.90-1.20) \times 1.05(0.92-1.42)$; and caeca: $19.7(13.3-31.7) \times 0.43(0.23-0.94)$.

Hosts: Hoplias intermedius (Günther, 1864) (new host) and Hoplias malabaricus (Bloch, 1794).

Site of infection: Coelomic cavity and the stomach of two hosts.

Voucher specimen: CHIOC 37984 (H. intermedius).

Remarks: In the São Francisco River, Brasil-Sato (2003) reported metacercariae of Ithyoclinostomum sp. in $H$. malabaricus. These metacercariae were generally found encysted in sites associated with natural body cavities, with openings to the exterior, or encysted in muscles (BELEI et al., 2013).

In the trahiras and "trairôes" from São Francisco River in this study, the prevalence values were lower $(10.67 \%$ and $5.81 \%$, respectively) than most of those of the $I$. dimorphum observed by some researchers, which were variable across the basins. Among trahiras, the prevalence was $14.3 \%$ in the Parque de Reserva and Refúgio Soóretama, State of Espírito Santo (calculated value by the authors from one fish parasitized of seven examined by TRAVASSOS et al., 1964); 41.1\% in the Paraná River (PAVANELLI et al., 1990), while suggested hematophagy due to the brown pigment noted in the caeca of the parasites; $17.9 \%$ in the lakes and dams from Santa Maria, State of Rio Grande do Sul (WEIBLEN \& BRANDÃO, 1992); 30.8\% in the Lages Reservoir, State of Rio de Janeiro (PARAGUASSÚ \& LUQUE, 2007); $42 \%$ in the lake of the Cachoeira do Sul municipality (GALLIO et al., 2007); 71.4\% (calculated value by the authors, from five parasitized fish of seven examined) of trahiras from Carioca 
Lake, mid-Doce River, State of Minas Gerais (BELEI et al., 2013); and $0.96 \%$ from $H$. malabaricus, and $2.94 \%$ from Hoplerytrinus unitaeniatus (Spix \& Agassiz, 1829) in the Arari Lake, Marajó Island, State of Pará (BENIGNO et al., 2014).

Benigno et al. (2014) studied the morphology of Ithyoclinostomum dimorphum (Diesing, 1850) Witenberg, 1926, and inventoried the presence of metacercariae of this species in fish and other hosts in Brazil (including their definitive hosts), and listed the sites of infection.

The present record of metacercariae of Ithyoclinostomum sp. in $H$. intermedius expands the list of known hosts of this species.

Gorgoderidae Looss, 1899

Phyllodistomum Braun, 1899

Phyllodistomum spatula Odhner, 1902

Measurements: (Based on four adult specimens "in toto") Body: 3.87 (3.07-4.67) × 3.29 (1.81-4.78); oral sucker: $0.56(0.49-0.62) \times 0.52(0.46-0.58)$; ventral sucker: $0.42(0.28-0.57)$ $\times 0.45$ (0.34-0.57); esophagus: 0.30 (0.27-0.33); ovary: $0.21(0.09-0.33) \times 0.26(0.13-0.39)$; right testicle: $0.25(0.13-0.37)$ $\times 0.24(0.10-0.39)$; left testicle: $0.26(0.14-0.39) \times 0.24(0.10-0.37)$; right vitelline gland: $0.14(0.11-0.18) \times 0.14(0.12-0.17)$; left vitelline gland: $0.13(0.09-0.16) \times 0.18(0.09-0.27)$; seminal vesicle: $0.08(0.05-0.11) \times 0.10(0.07-0.12)$; and eggs: $0.02(0.02-0.03)$ $\times 0.01(0.01-0.02)$.

Hosts: Hoplias intermedius (Günther, 1864) and Hoplias malabaricus (Bloch, 1794) (new hosts).

Site of infection: Urinary bladder and coelomic cavity of two hosts.

Voucher specimens: CHIOC 37985 (H. intermedius), CHIOC 37986 (H. malabaricus).

Remarks: Our specimens are similar to those reported by Lewis (1935) and Fernandes (1984). The specimens of P. spatula found in Hoplias spp. in this study are larger than those collected by Fernandes (1984) in the body cavity of Colossoma macropomum (Cuvier, 1816). However, the size of the specimens found in the present study, and those obtained by Fernandes (op. cit.), are within the amplitude recorded by Lunaschi \& Martorelli (1990) for parasites of the urinary bladder of Pimelodella laticeps Eigenmann, 1917 and Rhamdia sapo Valenciennes, 1836, both Hetapteridae, from the Province of Buenos Aires, Argentina. Thus, the observed variation in size may be due to the development of adults in different hosts.

In Brazil, Phyllodistomum spp. were registered from freshwater fish (P. rhamdiae Amato \& Amato, 1993, P. ruschii Travassos, Freitas \& Mendonça, 1964, and P. spatula) and from marine fish (P. mugilis Knoff \& Amato, 1992 and P. sampaioi Travassos, Kohn \& Motta, 1963), which were inventoried by Kohn et al. (2007).

The record of $P$. spatula in $H$. intermedius expands upon the known hosts, and their presence in erythrinids extends their geographical distribution to the Sáo Francisco River.

Faustulidae Poche, 1926

Pseudosellacotyla Yamaguti, 1953

Pseudosellacotyla lutzi (Freitas, 1941) Yamaguti, 1953

Measurements: (Based on 20 adult specimens mounted "in toto") Body: $0.48(0.28-0.59) \times 0.38(0.22-0.44)$; oral sucker: $0.08(0.06-0.11) \times 0.09(0.05-0.11)$; ventral sucker: $0.06(0.04-0.07)$ $\times 0.06$ (0.03-0.07); esophagus: 0.01 (0.01-0.02) long; pharynx:
$0.05(0.04-0.07) \times 0.05(0.03-0.06)$; ovary: $0.08(0.04-0.11)$ $\times 0.07(0.05-0.09)$; right testicle: $0.09(0.06-0.16) \times 0.09(0.04-0.11)$; left testicle: $0.11(0.05-0.13) \times 0.09(0.05-0.11)$; right vitelline gland: $0.13(0.06-0.19) \times 0.10(0.05-0.14)$; left vitelline gland: $0.12(0.05-0.16) \times 0.10(0.04-0.14)$; and eggs: $0.03(0.03-0.04)$ x $0.01(0.01)$.

Host: Hoplias intermedius (Günther, 1864) (new host).

Site of infection: Pyloric caeca.

Voucher specimens: CHIOC 37987 a, b, c (H. intermedius).

Remarks: This species, originally of $H$. malabaricus from the Ilha Seca, State of São Paulo, and allocated to the Nanophyetidae Wallace, 1935, was placed in the Heterophyidae Leiper, 1909, and later in the Microphallidae Ward, 1901. Bray (2008) - considering the lack of a cirrus sac in $P$. lutzi, monotypic, which has a close relationship with Pseudobacciger Nahhas \& Cable, 1964- proposed its allocation in Faustulidae.

In this study, $P$. lutzi was found only in $H$. intermedius. In Brazil, it has been previously reported in $H$. malabaricus from the Mogi Guaçu River, State of São Paulo, by Kohn et al. (1985), and from the Paraná River, State of Paraná, by Fernandes \& Kohn (2001). The general morphology was in accordance with the morphometry of the of the P. lutzi presented by Kohn et al. (1985). Some differences in the measurements are apparently attributable to intraspecific variation and/or to the effects of different methods used to collect and preserve the specimens.

The presence of $P$. lutzi in $H$. intermedius expands upon the list of known hosts, as well as the geographical distribution of this species.

\section{Discussion}

In this study on Digenea of erythrinids from the upper São Francisco River, there was a remarkable expression of larval Digenea, with a prevalence of metacercariae greater than that of adult digeneans.

In the case of metacercariae of Austrodiplostomum sp., which were already recorded in several fish (a generalist species at that stage of development) in the São Francisco River and other basins (see RAMOS et al., 2013), they were able, as active cercariae, to infect fish (which acted as a second intermediate host) and achieved a good distribution among them across the aquatic environment. In this study, the fact that cercariae of the Austrodiplostomum sp. actively infected fish was reflected in their high prevalence rate in relation to the prevalence of adults $P$. spatula and $P$. lutzi. These species require predation by fish of the first intermediate host in order for the adults to develop within them. In this case, a larval-stage transmission strategy for the fish, definitive hosts in the life cycle of these species, was one of the factors that promoted the different values in the prevalence rates reported in this study.

With regard to the metacercariae of Ithyoclinostomum sp. in this study, according to Dias et al. (2003), I. dimorphum shows a complex life cycle in which mollusks, fish, and birds act as hosts in the different life stages of the parasite. These were found in $H$. malabaricus from different Brazilian basins (PAVANELLI et al., 1990; GALLIO et al., 2007; PARAGUASSÚ \& LUQUE, 2007; BELEI et al., 2013), as well as in the São 
Francisco basin (BRASIL-SATO, 2003). In addition to these hosts, they were found in Schizodon borelli (Boulenger, 1900) by Machado et al. (1996). Adult specimens of I. dimorphum have been registered in birds in Brazil (i.e., Ardeidae, TRAVASSOS et al., 1969; ARRUDA et al., 2001; DIAS et al., 2003). Based on the parasitism of fish from the São Francisco and other basins, it is possible to state that these metacercariae do not have such a wide spectrum of second intermediate hosts in the aquatic environment when compared to the active and non-selective action of Austrodiplostomum sp..

The prevention of parasitism by metacercariae of Austrodiplostomum sp. is essential because they are known to diminish visual acuity in fish (BENIGNO et al., 2014); as such, they are ambush predators, and this can negatively affect their feeding and nutrition, impair their ability to avoid predators and, as a result, they become readily available and can catch prey easily. As a consequence, the conclusion of the parasites' life cycle in their definitive hosts is optimized. On the other hand, the parasitism of the Ithyoclinostomum sp. metacercariae can result in a rejection of meat consumption because of the repugnant appearance of the metacercariae, which are encapsulated and sometimes dark-colored; this is an interesting helminth from a health and hygiene point of view (BENIGNO et al., 2014). It damages production, as in the case of fish farms or the subsistence fishing of river populations. Therefore, metacercariae constitute parasitism, which ultimately threatens fish production directly (due to the possibility that the parasites can negatively affect the growth and weight gain of the fish; in particular, since the stocks decrease, they can become more vulnerable to predation, or their repugnant appearance may lead to discarding the fish), but their presence can be carefully prevented with a plan to farm the Erythrinidae.

The prevalence rates for metacercariae of the Austrodiplostomum sp. in preferentially piscivorous adult fish (the size reached at first sexual maturity) in the São Francisco River, in the case of C. kelberi (SANTOS-CLAPP \& BRASIL-SATO, 2014), and among the Erythrinidae in the present study, make it possible to indicate that the lower level of ingestion of organisms that act as a first intermediate host in the Digenea cycles had negatively affected the chance for fish to act as an intermediate host (other metacercariae, e.g., Clinostomum sp.) and definitive hosts (adult digeneans) for that group of parasites - whose transmission requires the predation of the first or second intermediate host, respectively. Thus, the analysis of the transmission mode (active or passive) of larval digeneans in fish, in association with knowledge about the feeding habits of the fish, helped in understanding the wide distribution of Austrodiplostomum sp., the reduction in the spectrum of species of fish containing parasites, as in the case of Ithyoclinostomum sp., and the low prevalence and smaller quantity of adult digeneans in piscivorous fish in comparison to those species of larger sized omnivorous fish of the upper São Francisco basin.

Phyllodistomum spatula has been registered in some types of characiform and siluriform hosts, and it can be considered a generalist species with regard to the definitive host. According to Lunaschi \& Martorelli (1990), who described the biological cycle of P. obtusa, this species has decapode crustaceans as the intermediate hosts. The low prevalence rates for Erythrinidae reflect the low availability of the intermediate hosts that are accessible to the fish; it may also indicate a preference for fish in their feeding habits, which is more likely, given that the fish tested in this study were adults in larger size classes relative to the species (LOUREIRO \& HAHN, 1996; MORAES \& BARBOLA, 1995), and they were also mainly piscivorous (ALVIM \& PERET, 2004).

Of the four Digenea species registered in this study, P. lutzi is the only species that, until then, had only been registered in $H$. malabaricus. In that study, P. lutzi occurred in H. intermedius; its presence was closely related to the Hoplias group, and it could be classified as a specialist parasite among Erythrinidae. Since its prevalence is low, it is possible that it is found in $H$. malabaricus from the São Francisco River, as well as in other congeneric species from other basins.

The presence of adult parasites is a consequence of the carnivorous habits of the Erythrinidae members of this study, and the two fish species acted as intermediate and definitive hosts in these biological cycles.

Records of the Austrodiplostomum sp. and Ithyoclinostomum sp. metacercariae, and of adult specimens of P. spatula and P. lutzi of $H$. intermedius in this study expand upon the list of known hosts for this species. The two species of Digenea adults represent new records of parasites of fish in the São Francisco basin.

\section{Acknowledgements}

We express appreciation to Dr Yoshimi Sato (CODEVASF, Três Marias, MG) for his kindness assistance during the collect of the fish; to Drs Osvaldo T. Oyakawa and Marcelo Knoff for receiving the voucher specimens of the fish and of the parasites in the MZUSP and CHIOC, respectively. Danielle P. C. Costa and Cassandra M. Monteiro were supported by PhD Fellowship and Post Doctoral Fellowship, respectively, from Coordenação de Aperfeiçoamento de Pessoal de Nível Superior (CAPES); This paper was partially supported by Capes, Edital Parasitologia Básica (nº 032/2010).

\section{References}

Alvim MCC, Peret AC. Food resources sustaining the fish fauna in a section of the upper São Francisco River in Três Marias, MG, Brazil. Braz J Biol 2004; 64(2): 195-202. http://dx.doi.org/10.1590/S151969842004000200003. PMid:15462291

Amato JFR, Boeger WA, Amato SB. Coleta e processamento de parasitos de pescado: protocolos para laboratório. Seropédica: Imprensa Universitária da Universidade Federal Rural do Rio de Janeiro; 1991.

Arruda VS, Pinto RM, Muniz-Pereira LC. New host and geographical records for helminths parasites of Ardeidae (Aves, Ciconiiformes) in Brazil. Rev Bras Zool2001; 18(S1): 225-232. http://dx.doi.org/10.1590/ S0101-81752001000500018.

Belei F, Ferreira SR, Perin LM, Braga FR, Sampaio WMS, Araújo JV, et al. First report of Austrodiplostomum compactum and Ithyoclinostomum dimorphum in trahira (Hoplias malabaricus) from the middle course of the rio Doce, Minas Gerais, Brazil. Arq Inst Biol 2013; 80(2): 249-252. http://dx.doi.org/10.1590/S1808-16572013000200017.

Benigno RN, Knoff M, Matos ER, Gomes DC, Pinto RM, Clemente SC. Morphological aspects of Clinostomidae metacercariae (Trematoda: Digenea) in Hoplerytrinus unitaeniatus and Hoplias malabaricus (Pisces: 
Erythrinidae) of the Neotropical region, Brazil. An Acad Bras Ciênc 2014; 86(2): 733-744. http://dx.doi.org/10.1590/0001-3765201420130025.

Brasil-Sato MC, Pavanelli GC. Digenea de Pimelodus maculatus (Osteichthyes, Pimelodidae) das bacias dos rios São Francisco e Paraná, Brasil. Parasitol Latinoam 2004; 59(3-4): 123-131. http://dx.doi.org/10.4067/S071777122004000300006

Brasil-Sato MC, Santos MD. Metazoan parasites of Conorhynchos conirostris (Valenciennes, 1840) an endemic siluriform fish of the São Francisco basin, Brazil. Rev Bras Parasitol Vet 2005; 14(4): 160-166. PMid:16445873.

Brasil-Sato MC. Parasitos de peixes da Bacia do São Francisco. In: Godinho HP, Godinho AL. Águas, peixes e pescadores do São Francisco das Minas Gerais. Belo Horizonte: Pucminas; 2003. p. 149-166.

Bray RA. Family Faustulidae Poche, 1926. In: Bray RA, Gibson DI, Jones A. Keys to the Trematoda. Wallingford: CAB International and The Natural History Museum; 2008. vol. 3, p. 509-522.

Britski HA, Sato Y, Rosa ABS. Manual de identificação de peixes da região de Três Marias (com chaves de identificação para os peixes da Bacia do São Francisco). 3rd ed. Brasília: Codevasf - Câmara dos Deputados; 1988.

Bush AO, Lafferty KD, Lotz JM, Shostak AW. Parasitology meets ecology on its own terms: Margolis et al. revisited. J Parasitol 1997; 83(4): 575 583. http://dx.doi.org/10.2307/3284227. PMid:9267395

Campbell RA. Family Gorgoderidae Looss, 1899. In: Bray RA, Gibson DI, Jones A. Keys to the Trematoda. Wallingford: CAB International and The Natural History Museum; 2008. vol. 3, p. 191-2014.

Carvalho LN, Fernandes CHV, Moreira VSS. Alimentação de Hoplias malabaricus (Bloch, 1794) (Osteichthyes, Erythrinidae), no rio Vermelho, Pantanal Sul-Matogrossense. Rev Bras Zoociênc 2002; 4(2): 227-236.

Cohen SC, Justo MCN, Kohn A. South American Monogenoidea parasites offishes, amphibians and reptiles. Rio de Janeiro: Oficina de Livros; 2013.

Dias MLGG, Eiras JC, Machado MH, Souza GTR, Pavanelli GC. The life cycle of Clinostomum complanatum Rudolphi, 1814 (Digenea, Clinostomidae) on the floodplain of the high Paraná river, Brazil. Parasitol Res 2003; 89(6): 506-508. http://dx.doi.org/10.1007/s00436-002-0796-z. PMid:12658465.

Fernandes BMM, Kohn A. On some trematodes parasites of fishes from Paraná River. Braz J Biol 2001; 61(3): 461-466. http://dx.doi.org/10.1590/ S1519-69842001000300016. PMid:11706574

Fernandes BMM. New host, geographical record and a synonym for Phyllodistomum spatula Odhner, 1902 (Trematoda, Gorgoderidae). Mem Inst Oswaldo Cruz 1984; 79(2): 263-265. http://dx.doi.org/10.1590/ S0074-02761984000200014.

Gallio M, Silva AS, Soares JF, Silva MK, Salomão EL, Monteiro SG. Ocorrência de Metacercárias de Ithyoclinostomum dimorphum em traíras no Rio Grande do Sul, Brasil: relato de caso. Estud Biol 2007; 29(6869): 337-339.

Jones A, Bray RA, Gibson DI. Keys to Trematoda. London: Cab International and The Natural History Museum; 2005. vol. 2.

Kanev I, Radev V, Fried B. Family Clinostomidae Lühe, 1901. In: Gibson DI, Jones A, Bray RA. Keys to the Trematoda. London: CABI Publishing and the Natural History Museum; 2002. vol. 1, p. 113-120.

Kohn A, Fernandes BMM, Baptista-Farias MFD. Metacercariae of Diplostomum (Austrodiplostomum) compactum (Trematoda, Diplostomatidae) in the eyes of Plagioscion squamosissimus (Teleostei, Sciaenidae) from the Reservoir of the Hydroelectric Power Station of Itaipu, Brazil. Mem
Inst Oswaldo Cruz 1995; 90(3): 341-344. http://dx.doi.org/10.1590/ S0074-02761995000300005.

Kohn A, Fernandes BMM, Cohen SC. South american trematodes parasites of fishes. Rio de Janeiro: Imprinta Express; 2007.

Kohn A, Fernandes BMM, Macedo B, Abramson B. Helminths parasites of freshwater fishes from Pirassununga, SP, Brazil. Mem Inst Oswaldo Cruz 1985; 80(3): 327-336. http://dx.doi.org/10.1590/S007402761985000300009 .

Kohn A, Moravec F, Cohen SC, Canzi C, Takemoto RM, Fernandes BMM. Helminths of freshwater fishes in the reservoir of the hydroelectric power station of Itaipu, Paraná, Brazil. Check List 2011; 7(5): 681-690.

Lewis FJ. The trematode genus Phyllodistomum Braun. Trans Am Microsc Soc 1935; 54(2): 103-117. http://dx.doi.org/10.2307/3222118.

Loureiro VE, Hahn NS. Dieta e atividade alimentar da traíra, Hoplias malabaricus (Bloch, 1794) (Osteichthyes, Erythrinidae), nos primeiros anos de formação do Reservatório de Segredo - PR. Acta Limnol Bras 1996; 8: 195-205.

Lunaschi LI, Martorelli SM. Presencia de Phyllodistomum spatula Odhner (Trematoda-Gorgoderidae) en dos especies de pimelodidos capturados en la Provincia de Buenos Aires, Argentina. Aportes al conocimiento de su ciclo biologico. Neotropica 1990; 36(95): 55-63.

Machado MH, Pavanelli GC, Takemoto RM. Structure and diversity of endoparasitic infracommunities and the trophic level of Pseudoplatystoma corruscans and Schizodon borelli (Osteichthyes) of the high Paraná River. Mem Inst Oswaldo Cruz 1996; 91(4): 441-448. http://dx.doi.org/10.1590/ S0074-02761996000400010. PMid:9070406

Machado PM, Takemoto RM, Pavanelli GC. Diplostomum (Austrodiplostomum) compactum (Lutz, 1928) (Platyhelminthes, Digenea) metacercariae in fish from the floodplain of the Upper Paraná River, Brazil. Parasitol Res 2005; 97(6): 436-444. http://dx.doi.org/10.1007/s00436-005-1483-7. PMid:16151731

Martins ML, Fujimoto RY, Nascimento AA, Moraes FR. Ocorrência de Diplostomum sp Nordmann, 1832 (Digenea: Diplostomidae) em Plagioscion squamosissimus Heckel, 1840 proveniente do reservatório de Volta Grande, MG, Brasil. Acta Sci Anim Sci 1999; 21(2): 263-266.

Moraes MFPG, Barbola IF. Hábito alimentar e morfologia do tubo digestivo de Hoplias malabaricus (Osteichthyes; Erythrinidae) da Lagoa Dourada, Ponta Grossa, Paraná, Brasil. Acta Biol Par 1995; 24(1-4): 1-23.

Niewiadomska K. Family Diplostomidae Poirier, 1886. In: Gibson DI, Jones A, Bray RA. Keys to the Trematoda. London: CABI Publishing and the Natural History Museum; 2002. vol. 1, p. 167-196.

Oyakawa OT, Akama A, Mautari KC, Nolasco JC. Peixes de Riachos da Mata Atlântica: nas unidades de conservação do Vale do Rio Ribeira de Iguape no Estado de São Paulo. São Paulo: Neotropica; 2006.

Oyakawa OT, Mattox GMT. Revision of the Neotropical trahiras of the Hoplias lacerdae species-group (Ostariophysi: Characiformes: Erythrinidae) with descriptions of two new species. Neotrop Ichthyol 2009; 7(2): $117-$ 140. http://dx.doi.org/10.1590/S1679-62252009000200001.

Oyakawa OT. Family Erythrinidae. In: Reis RE, Kulander SO, Ferraris CJ Jr. Check list of the freshwater fishes of South and Central America. Porto Alegre: Edipucrs; 2003. p. 238-240.

Paes JVK, Carvalho ED, Silva RJ. Infection by Austrodiplostomum compactum metacercariae in fish from the Nova Avanhandava Reservoir, Tietê River, São Paulo State, Brazil. Acta Sci Biol Sci 2010a; 32(3): $273-$ 278. http://dx.doi.org/10.4025/actascibiolsci.v32i3.5675. 
Paes JVK, Carvalho ED, Silva RJ. Infection levels of Austrodiplostomum compactum (Digenea, Diplostomidae) metacercariae in Plagioscion squamosissimus (Teleostei, Sciaenidae) from the Nova Avanhandava reservoir, São Paulo State, Brazil. J Helminthol 2010b; 84(3): 284-291. http://dx.doi.org/10.1017/S0022149X09990617. PMid:19889255

Paraguassú AR, Luque JL. [Metazoan parasites of six fishes species from Lajes Reservoir in the State of Rio de Janeiro, Brazil]. Rev Bras Parasitol Vet 2007; 16(3): 121-128. http://dx.doi.org/10.1590/S198429612007000300002 . PMid:18078597.

Pavanelli GC, Schaeffer GV, Machado MH. Ocorrência e histopatologia de metacercárias de Ichtyoclinostomum dimorphum (Diesing, 1850) (Trematoda - Clinostomidae) em traíras coletadas no rio Paraná. Rev Unimar 1990; 12(1): 69-75.

Ramos IP, Franceschini L, Zago AC, Zica EO, Wunderlich AC, Carvalho $\mathrm{ED}$, et al. New host records and a checklist of fishes infected with Austrodiplostomum compactum (Digenea: Diplostomidae) in Brazil. Rev Bras Parasitol Vet 2013; 22(4): 511-518. http://dx.doi.org/10.1590/ S1984-29612013000400010. PMid:24473875

Rocha CAM. Parasitic helminths of the freshwater neotropical fish Hoplias malabaricus (Characiformes, Erythrinidae) from South America basins. Rev Fish Sci 2011; 19(2): 150-156. http://dx.doi.org/10.1080/ 10641262.2011.557752.

Sabas CSS, Brasil-Sato MC. Helminth fauna parasitizing Pimelodus pohli (Actinopterygii: Pimelodidae) from the upper São Francisco River, Brazil. Rev Bras Parasitol Vet 2014; 23(3): 375-382. http://dx.doi.org/10.1590/ S1984-29612014067. PMid:25271459

Santos RS, Marchiori N, Santarem VA, Takahashi K, Mourino JLP, Martins ML. Austrodiplostomum compactum (Lutz, 1928) (Digenea, Diplostomidae) in the eyes of fishes from Paraná River, Brazil. Acta Sci Biol Sci 2012; 34(2): 225-231. http://dx.doi.org/10.4025/actascibiolsci. v34i 2.9337.

Santos-Clapp MD, Brasil-Sato MC. Comunidade parasitária de Cichla kelberi (Perciformes, Cichlidae) do Reservatório de Três Marias, Minas
Gerais, Brasil. Rev Bras Parasitol Vet 2014; 23(3): 367-374. http://dx.doi. org/10.1590/S1984-29612014059. PMid:25271458

Szidat L, Nani A. Diplostostomiasis cerebralis del pejerrey: una grave epizootia que afecta la economia nacional producida por larvas de trematodes que destruyen el cerebro de los pejerreys. Rev Mus Argent Cienc Nat 1951; 1(8): 323-384.

Thatcher VE. Amazon fish parasites. Amazoniana 1991; 11(3-4):263-572.

Travassos L, Teixeira de Freitas JF, Kohn A. Trematódeos do Brasil. Mem Inst Oswaldo Cruz 1969; 67(1): 1-886. PMid:5397756.

Travassos L, Freitas JFT, Mendonça JM. Relatório da excursão do Instituto Oswaldo Cruz ao Parque de Reserva e Refúgio Soóretama, no estado do Espírito Santo, em outubro de 1963. Bol Mus Biol Prof. Mello-Leitäo. Zoologia 1964; 23: 1-26.

Weiblen AM, Brandão DA. Levantamento parasitológico em Hoplias malabaricus, Bloch, (1794) (traíra) de águas da regiāo de Santa Maria-RS. Cienc Rural 1992; 22(2): 203-208. http://dx.doi.org/10.1590/S010384781992000200014

Yamada FH, Moreira LHA, Ceschini TL, Takemoto RM, Pavanelli GC. Novas ocorrências de metacercária de Austrodiplostomum compactum (Lutx, 1928) (Platyhelminthes: Digenea) parasito de olhos de peixes da Bacia do Rio Paraná. Rev Bras Parasitol Vet 2008; 17(3): 163-166. http:// dx.doi.org/10.1590/S1984-29612008000300010. PMid:19245765

Zago AC, Franceschini L, Zocoller-Seno MC, Veríssimo-Silveira R, Maia AAD, Ikefuti CV, et al. The helminth community of Geophagus proximus (Perciformes: Cichlidae) from a tributary of the Paraná River, Ilha Solteira Reservoir, São Paulo State, Brazil. J Helminthol 2013; 87(2): 203-211. http://dx.doi.org/10.1017/S0022149X12000223. PMid:22716964

Zica EOP, Wunderlich AC, Ramos IP, Silva RJ. Austrodiplostomum compactum (Lutz, 1928) (Digenea, Diplostomidae) infecting Geophagus proximus Castelnau, 1855 (Cichlidae, Perciformes) in the Tietê River, Nova Avanhandava Reservoir, Municipality of Buritama, São Paulo State, Brazil. Neotrop Helminthol 2010; 4(1): 9-15. 